\title{
Physicochemical Properties, Oxidative Stability, and Sensory Quality of Lamb Sausage Added with Green Tea Leaves (Camelia sinensis) Powder
}

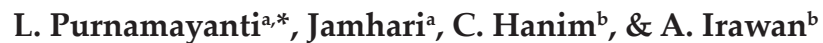 \\ ${ }^{a}$ Department of Animal Products Technology, Faculty of Animal Science, Universitas Gadjah Mada \\ ${ }^{b}$ Department of Animal Nutrition and Feed Science, Faculty of Animal Science, Universitas Gadjah Mada \\ Jalan Fauna No. 03 Bulaksumur 52881 Yogyakarta, Indonesia \\ *Corresponding author: lailatul.purnamayanti@mail.ugm.ac.id \\ (Received 15-08-2019; Revised 21-10-2019; Accepted 11-11-2019)
}

\begin{abstract}
Green tea leaves as a source of natural antioxidants has a huge potential to improve sausage quality from lamb meat, in line with an increase of people concern in functional food products. This study aimed to evaluate inclusion of green tea leaves (Camelia sinensis) powder (GTP) into lamb sausage on physicochemical properties, total microbes, oxidative stability, and sensory quality. Three lambs aged one year was slaughtered as sausage meat source. Incorporation of $0.0 \%$, $1.0 \%, 1.5 \%$, and $2.0 \%$ GTP to lamb sausage during 0,7 , and 14 days of storage was conducted in a completely randomized design of ANOVA with five replications in each treatment. Few changes were observed on chemical and physical qualities by adding $1 \%$ GTP, particularly on protein and water holding capacity (WHC) $(\mathrm{p}<0.05)$, while moisture, fat, $\mathrm{pH}$, and tenderness were not affected $(\mathrm{p}>0.05)$. Lipid oxidation and the number of total plate count (TPC) were reduced by $36 \%-40 \%$ and $31 \%-49 \%$, respectively by the inclusion of $1 \%$ GTP during storage time $(p<0.05)$. Adding GTP negatively affected the sensory quality of lamb sausage since the score of acceptability reduced in the group of sausages contained GTP although the scores for color, flavor, and odor were higher with GTP addition. The incorporation of GTP was effectively inhibiting bacterial growth and lipid oxidation in the lamb sausage. However, GTP was also ineffective at improving the sensory quality of the sausage.
\end{abstract}

Keywords: green tea powder; lamb sausage; oxidative stability; sensory quality

\section{INTRODUCTION}

In recent years, increasing awareness of consumers to avoid adverse effects of synthetic preservatives and demand for functional sausages are encouraging industry to develop a novel multipurpose ingredient (Lorenzo et al., 2018) to develop functional food. Manufacturing lamb meat as a sausage has a great potential in the Indonesian market since it is rarely available. Additionally, sausage is also an alternative lamb meat processing to minimize its strong odor and flavor (Listyarini et al., 2018). Strong odor, known as mutton smell, that associated with lamb meat is attributed to aldehyde, ketone, and volatile compounds found in fat such as 4-methyloctanoic acid, 6-methylheptanoic acid, n-octanoic acid, etc. (Cai et al., 2015). Since lamb meat contains higher fat content (17\%-21\% fat) and fatty acids that responsible to produce a stronger flavor and odor than goat (2.3\%-3.0\% fat) and beef (5-12\% fat) (Cai et al., 2015), it also promotes a faster deterioration due to an extensive lipid oxidation (Aminzare et al., 2018; Silva et al., 2018), primarily when processed as a sausage. During the deteriorative process, a variety of toxic compounds are produced from meat and negatively affect consumer's health (Jayawardana et al., 2019). There are several factors accelerating shelf life, sensory quality, and stability of sausage, including fatty acids profile, oxygen, meat pigments, preservation methods, and substitution strategy (Silva et al., 2018). These primary mechanisms of quality deterioration limit shelf-life through changes in flavor, texture, and color (Alirezalu et al., 2019).

Along with an increase in people's concern in healthy food, people now psychologically prefer to select meat products with a natural preservative agent (Lorenzo et al., 2018; Schilling et al., 2018). Therefore, the current industrial trend of manufacturing meat products has shifted towards natural antioxidants derived from various plant materials that are rich in radical-scavenging polyphenols as preservative agents (Franco et al., 2018; Wang et al., 2019).

Among natural antioxidant sources, green tea (Camellia sinensis L) extract is the most widely known plant rich in phenolic compounds such as flavonoids, flavanols, phenolic acids, and others, and even higher phenolic content compared to black tea (Jayawardana et al., 2019) that play an important role as an antioxidant. Several studies revealed that green tea extract enhanced meat quality characteristics such as meat color, tenderness, and shelf life in ruminant livestock, and helped to reduce lamb meat odor by inhibiting specific lipid and protein component to the oxidation (Zhong et al., 2015). 
There were also reported by some authors that green tea extracts have antibacterial (against gram-positive as well as gram-negative bacteria), antiviral, antifungal, and radical scavenging activity (Perumalla \& Hettiarachchy, 2011) associated with their antioxidant properties (Bansal et al., 2013), that potentially avoid the sausage from spoilage by microbial contamination. In addition, oxidative stability of meats also improved by adding green tea extract as shown in their lower TBARS values (Schilling et al., 2018).

Despite green tea extracts as natural antioxidant agents were globally studied in a variety of meats and food (Jongberg et al., 2018), there is still limited evidence in lamb sausage. The mechanism of specific natural compounds in inhibiting the oxidation of processedmeat products has also been comprehensively reviewed (Jiang \& Xiong, 2016). Among these compounds, there was no data on lamb sausage. Since lamb sausages are riskier to be deteriorated and contaminated by microorganism due to their fat content, and its natural color is relatively not attractive for consumers, it is interesting to examine the power of green tea powder in elevating sausages quality. Incorporation of plant antioxidants into meat products effectively prevents lipid oxidation when added in optimal amount. Thus, in the present study, we evaluated the microbial inhibitory effect, oxidative stability, and sensory quality of lamb meat sausage added with various levels of green tea leaves powder during $14 \mathrm{~d}$ of storage.

\section{MATERIALS AND METHODS}

\section{Preparation of Green Tea Leaves Powder}

The tea leaves were obtained from local tea farmers (Yogyakarta, Indonesia) by picking from the first to the third leaves and washed thoroughly and then dried by three different methods: oven-dried, freeze-dried, and freeze-dried vacuum, to test the highest antioxidant activity among the drying methods. Briefly, for oven-dried method, green tea leaves were packed in the paper bag and oven-dried at $55^{\circ} \mathrm{C}$ for $3 \mathrm{~d}$ while in the freeze-dried vacuum, the green tea leaves were packed in vacuum condition and freeze-dried (LABCONC corp., Missouri) at $-20^{\circ} \mathrm{C}$ for ten $\mathrm{h} / \mathrm{d}$ until the moisture was evaporated. Afterward, the leaves were then ground and sifted a 100 $\mu \mathrm{m}$ in sieve. Thereafter, the antioxidant activity for each drying method was determined by DPPH (1, 1diphenyl2-picryl hydrazyl) assay in triplicate by following the protocol of Shekhar \& Anju (2014). The Trolox calibration curve was drawn using inhibition percentage and Trolox concentration (\%).

\section{Experimental Sausage Preparation}

All spices material purchased from the local market in Yogyakarta. The lamb meat was slaughtered from three lambs with a similar breed, age, and weight. The sausage production process was conducted at the Laboratory of Meat Technology, Faculty of Animal Science, Universitas Gadjah Mada. Lamb sausage was prepared according to the following formulation (per 1 $\mathrm{kg}$ sausage): lamb meat shoulder (750 g), back fat (150 g), skim milk (70 g), tapioca starch (15 g), salt (23 g), sugar (120 g), garlic coriander $(20 \mathrm{~g})$, sodium nitrite $(0.2$ $\mathrm{g})$, and MSG $(2 \mathrm{~g})$. The meat was chopped and finely ground with a grinder. The treatments were four levels of green tea leaves powder (GTP) that were added into the sausage formula: GTP0= sausage without GTP addition; GTP1= sausage $+1 \%$ GTP; GTP1.5= sausage + $1.5 \%$ GTP; and GTP2 $=$ sausage $+2 \%$ GTP. Each group of treatment was replicated five times. The minced lamb meat was weighed and added with salt, garlic, pepper, cilantro, and cooking oil to taste until all the ingredients were mixed evenly. Each dough was added skim milk and tapioca flour and processed according to Nowak et al. (2016). Five packages from each treatment were randomly selected after 0,7 , and $14 \mathrm{~d}$ of display in refrigerator at $4^{\circ} \mathrm{C}$ and subjected to physicochemical, microbiological, and sensory analysis. Consumer acceptability was determined after $8 \mathrm{~d}$ of retail display.

\section{Physicochemical and $\mathrm{pH}$ Analysis}

Chemical composition of sausages including moisture, protein, fat, and ash contents was determined according to AOAC official method at 0, 7, 14, and $21 \mathrm{~d}$ of storage (AOAC, 2005) using a Near-Infrared (NIR) Spectrophotometer (Model 78,810; Foss Co., Hillerød, Denmark). The $\mathrm{pH}$ of lamb sausages was measured with a digital pH-meter (HI 99163, Hanna Instruments, Eibar, Spain) using minced sausage and distilled water (1:1, $\mathrm{p} / \mathrm{v})$.

Peroxide value was determined by following the principle method of Kong \& Singh (2011) and expressed as milliequivalents (meq). Briefly, $3 \mathrm{~g}$ of sausage sample was heated in 250-mL Erlenmeyer flask for $3 \mathrm{~min}$ at $60^{\circ} \mathrm{C}$ and then agitated for $3 \mathrm{~min}$ with $30 \mathrm{~mL}$ of acetic acid-chloroform solution $(3: 2 \mathrm{v} / \mathrm{v})$ to dissolve the fat. Following this protocol, the sausage particle was removed using Whatman paper No. 1 and added with potassium iodine solution $(0.5 \mathrm{~mL})$ to filtrate and followed with starch addition as an indicator. The peroxide value $(\mathrm{PV})$ was calculated as $\mathrm{PV}=(\mathrm{S} \times \mathrm{N}) / \mathrm{W} \times 100$, where $\mathrm{S}$ is titration volume, $\mathrm{N}$ is normality of sodium thiosulfate solution $(\mathrm{N}=0.01)$, and $\mathrm{W}$ is the sample weight $(\mathrm{g})$.

In addition, water holding capacity (WHC) was measured according to Warner (2014) by filter paper press method. Each piece of sausage was covered with filter paper and pressed with a $12 \mathrm{~kg}$ load for $2 \mathrm{~min}$ and the WHC was calculated as follows:

$$
\text { WHC }(\%)=[1-(\mathrm{Wa}-\mathrm{Wb}) /(\mathrm{Wa} \times \mathrm{M})] \times 100
$$

where $\mathrm{Wa}$ is meat weight before pressing, $\mathrm{Wb}$ is meat weight after pressing, and $\mathrm{M}$ is moisture content $(\mathrm{g})$. Sausage tenderness was tested using Warner Bratzler's shear force device (C-LM3B, Beijing, China) (AMSA, 1995).

\section{Microbial Analysis}

Analysis of total microbial with total plate count (TPC) was conducted based on the Indonesian National Standard method (SNI 2897; 2015). Samples of $25 \mathrm{~g}$ 
from randomly selected sausages from each group were homogenized with $225 \mathrm{~mL}$ of sterilized $0.85 \%$ physiological saline for $1 \mathrm{~min}$. The TPC was determined on Plate Count Agar (PCA, Merck, Darmstadt, Germany) at $37.8^{\circ} \mathrm{C}$ for 24 hours and enumerated. All counts of TPC from sausages sample were expressed as Log CFU/g.

\section{Sensory Characteristics Evaluation}

The sensory evaluation was conducted to evaluate whether the addition of green tea powder affected the sensory characteristics of lamb sausages. The sensory evaluation used in this study was a qualitative test with structured questionnaire protocol that was developed according to Sulmiyati et al. (2019) with a modification. A 15 well-trained students and laboratory staff (aged between 24-30 years) who were familiar with sausage sensory evaluation were recruited to evaluate 5 sausage samples. During the sensory tests, water and unsalted crackers were used for cleansing the mouth between sausage samples. The panelists were given questionnaire for each sample to evaluate the sensory quality using a non-structured hedonic scale consisting of 5 levels, including intensity of color ( $1=$ light green, $5=$ green), favor $(1=$ very dislike, $5=$ very like), freshness odor $(1=$ very non-fragrant smell, $5=$ very fragrant smell), and Texture ( $1=$ very soft, $5=$ very firm), and overall acceptability ( $1=$ very unacceptable, $5=$ very acceptable). The mean value of each group was calculated after the evaluation for each parameter.

\section{Statistical Analysis}

The data of nutrient composition, physicochemical quality, oxidative stability, and total plate count were included in the statistical analysis. These data from each days of storage were subjected to a completely randomized design (CRD) and analyzed according to one-way ANOVA using the GLM procedure within the SAS program (v.9, SAS Institute, USA) where levels of green tea leaves powder $(\mathrm{GTP} 0=$ sausage without GTP addition; GTP1= sausage + 1\% GTP; GTP1.5= sausage + 1.5\% GTP; and GTP2 $=$ sausage $+2 \%$ GTP) set as fixed effect and replication (five replications per treatment) set as a random effect. Duncan's new multiple range test was used when $\mathrm{p}<0.05$ to determine significant differences among the treatments. In addition, data of sensory quality were analyzed descriptively by comparing means score for each variable.

\section{RESULTS}

\section{Antioxidant Activity of Green Tea Leaves Powder with Different Drying Methods}

Prior to inclusion in the sausage, green tea leaves were dried by three different methods: oven-dried at $55^{\circ} \mathrm{C}$ (method 1), freeze-dried at $-20^{\circ} \mathrm{C}(\operatorname{method} 2)$, and packed with plastic vacuum + freeze-dried at $-20^{\circ} \mathrm{C}$ (method 3) to obtain the highest antioxidant activity. Data on antioxidant activity were provided in Figure 1. The method 3 resulted in a significantly higher anti- oxidant activity compared with method 2 and method $1(89.81 \%$ vs $84.36 \%$ vs $78.39 \%$, respectively). Since the method 3 provided the best quality of GTP, the GTP produced from this method was used as a treatment for sausage quality.

\section{Chemical Composition and Physical Characteristics}

Chemical properties of lamb sausages are reported in Table 1. As expected, the moisture and fat content of lamb sausages were not affected by the addition of GTP among the levels of $1 \%, 1.5 \%$, and $2 \%$ compared to the control group since the same quantity of raw materials were used in all experimental treatments. No significant difference was also observed during storage time. The moisture content and fat content of all lamb sausages range from $60.80 \%-64.25 \%$ and $6.57 \%-7.96 \%$, respectively. However, protein content significantly decreased prior to GTP inclusions $(p<0.05)$. The present study showed that the addition of GTP up to $2 \%$ did not influence the $\mathrm{pH}$, water holding capacity (WHC), and tenderness of lamb sausages as shown in Table 2.

\section{Oxidative Stability and Total Plate Count}

In the present study, peroxide value was used as a lipid oxidation indicator in the lamb sausage and the results are presented in Figure 2. The peroxide values significantly decreased with the addition of GTP $(\mathrm{p}<0.05)$. However, there was no different among $1 \%, 1.5 \%$, and $2 \%$ of GTP levels ( $p>0.05$ ). Prior to days of storage, similar results were also noticed.

The total plate count (TPC) of lamb sausages are shown in Figure 3. The addition of 1\% GTP significantly suppressed the number of TPC in comparison with the control treatment $(p<0.05)$ for all storage time $(0 d, 7$ $\mathrm{d}$, and $14 \mathrm{~d}$ ). The initial counts for TPC during storage were $4.12 \pm 0.12,5.03 \pm 0.91,5.46 \pm 1.12 \mathrm{Log}$ CFU/gram for 0 d, $7 \mathrm{~d}$, and $14 \mathrm{~d}$, respectively. The numbers significantly decreased by $31 \%, 49 \%$, and $32 \%$ for the respective storage time in the group contained $1 \%$ of GTP.

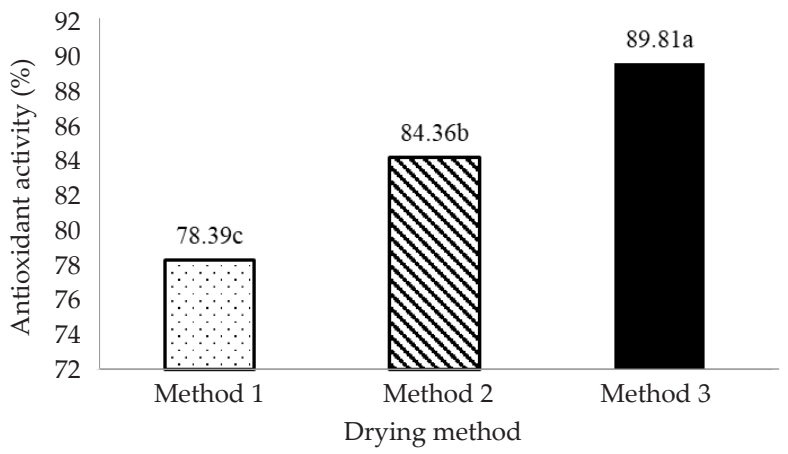

Figure 1. Antioxidant activity (\%) of green tea leaves evaluated with different drying methods. Method $1(\Gamma:)=$ ovendried at $55^{\circ} \mathrm{C}$; method $2(\mathbf{S})=$ freeze-dried at $-20^{\circ} \mathrm{C}$; method $3(\boldsymbol{\square})$ = packed with plastic vacuum + freezedried at $-20^{\circ} \mathrm{C}$. Different superscripts in the figure differ significantly $(\mathrm{p}<0.05)$. 
Table 1. Chemical composition of lamb sausage as influenced by the levels of green tea leaves powder (GTP) and storage time at a refrigerator temperature

\begin{tabular}{lcccc}
\hline \multirow{2}{*}{ Variables } & Levels of GTP & \multicolumn{3}{c}{ Days of storage } \\
\cline { 3 - 4 } & & 0 & 7 & 14 \\
\hline Moisture (\%) & $0.0 \%$ & $63.02 \pm 0.37$ & $63.14 \pm 2.14$ & $64.25 \pm 2.68$ \\
& $1.0 \%$ & $60.96 \pm 1.62$ & $62.10 \pm 1.91$ & $63.12 \pm 3.25$ \\
& $1.5 \%$ & $60.80 \pm 2.12$ & $62.50 \pm 1.37$ & $62.10 \pm 2.20$ \\
Protein content (\%) & $2.0 \%$ & $60.53 \pm 2.59$ & $61.54 \pm 2.03$ & $62.06 \pm 2.80$ \\
& $0.0 \%$ & $17.40 \pm 0.70^{\mathrm{a}}$ & $16.80 \pm 1.16^{\mathrm{a}}$ & $16.89 \pm 2.16^{\mathrm{a}}$ \\
& $1.0 \%$ & $15.97 \pm 0.85^{\mathrm{b}}$ & $16.20 \pm 1.23^{\mathrm{ab}}$ & $16.47 \pm 1.31^{\mathrm{a}}$ \\
Fat content (\%) & $1.5 \%$ & $15.66 \pm 1.34^{\mathrm{b}}$ & $15.73 \pm 0.94^{\mathrm{b}}$ & $15.36 \pm 0.60^{\mathrm{b}}$ \\
& $2.0 \%$ & $15.76 \pm 1.29^{\mathrm{b}}$ & $15.56 \pm 0.70^{\mathrm{b}}$ & $15.55 \pm 0.36^{\mathrm{b}}$ \\
& $0.0 \%$ & $7.84 \pm 2.12$ & $7.96 \pm 2.63$ & $7.74 \pm 2.82$ \\
& $1.0 \%$ & $7.73 \pm 2.87$ & $7.56 \pm 3.04$ & $7.13 \pm 3.17$ \\
& $1.5 \%$ & $7.55 \pm 2.45$ & $6.91 \pm 2.82$ & $6.57 \pm 2.49$ \\
\end{tabular}

Note: Means in the same column with different superscripts differ significantly $(\mathrm{p}<0.05)$.

Table 2. Physical qualities of lamb sausage as influenced by the levels of green tea leaves powder (GTP) and storage time at a refrigerator temperature

\begin{tabular}{lcccc}
\hline \multirow{2}{*}{ Variables } & Levels of GTP & \multicolumn{3}{c}{ Days of storage } \\
\cline { 3 - 4 } $\mathrm{pH}$ & $0.0 \%$ & 0 & 7 & 14 \\
& $1.0 \%$ & $6.50 \pm 0.17$ & $6.47 \pm 0.15$ & $6.47 \pm 0.11$ \\
& $1.5 \%$ & $6.47 \pm 0.11$ & $6.43 \pm 0.11$ & $6.43 \pm 0.15$ \\
& $2.0 \%$ & $6.40 \pm 0.17$ & $6.37 \pm 0.15$ & $6.37 \pm 0.11$ \\
Water holding capacity (\%) & $0.0 \%$ & $25.23 \pm 7.68$ & $39.05 \pm 1.61$ & $6.33 \pm 0.11$ \\
& $1.0 \%$ & $23.67 \pm 10.62$ & $34.52 \pm 7.15$ & $39.13 \pm 5.35$ \\
& $1.5 \%$ & $21.57 \pm 2.83$ & $28.30 \pm 4.27$ & $34.53 \pm 5.05$ \\
Tenderness $\left(\mathrm{kg} / \mathrm{cm}^{3}\right)$ & $2.0 \%$ & $23.71 \pm 5.90$ & $31.18 \pm 1.49$ & $32.26 \pm 4.05$ \\
& $0.0 \%$ & $0.87 \pm 0.31$ & $0.97 \pm 0.38$ & $31.23 \pm 0.33$ \\
& $1.0 \%$ & $0.87 \pm 0.31$ & $0.87 \pm 0.31$ & $1.03 \pm 0.58$ \\
& $1.5 \%$ & $0.73 \pm 0.23$ & $0.77 \pm 0.12$ & $0.90 \pm 0.36$ \\
\end{tabular}

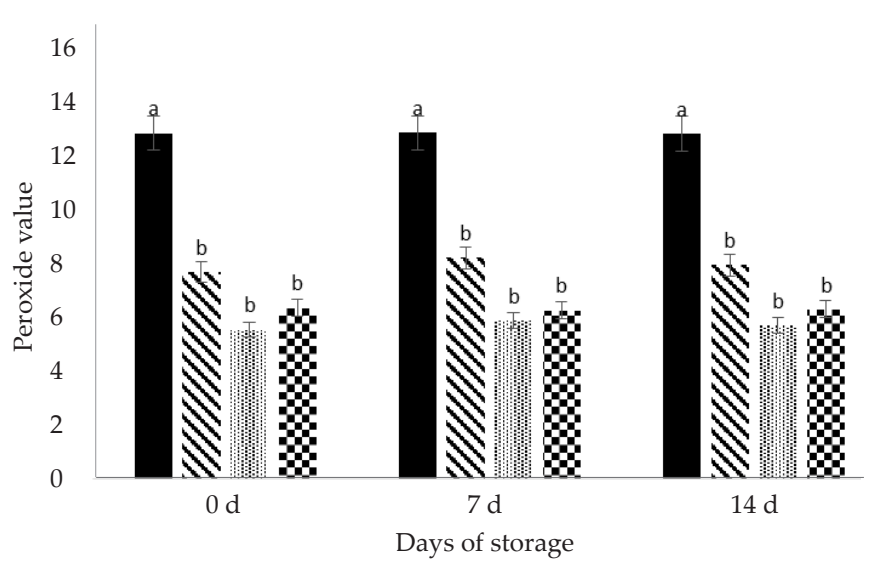

Figure 2. Peroxide value of lamb sausage as influenced by the levels of green tea leaves powder (GTP) during days of storage at a refrigerator temperature. GTP $=$ Green tea powder; CON GTP $0 \%(\boldsymbol{\square})=$ control, sausage with no GTP addition; GTP $1 \%(\mathbf{N})=$ sausage + $1 \%$ GTP; GTP $1.5 \%(\bar{\pi})=$ sausage $+1.5 \%$ GTP; GTP $2 \%(\mathbf{R})=$ sausage $+2 \%$ GTP. Different superscripts in the same group (days of storage) differ significantly $(\mathrm{p}<0.05)$.

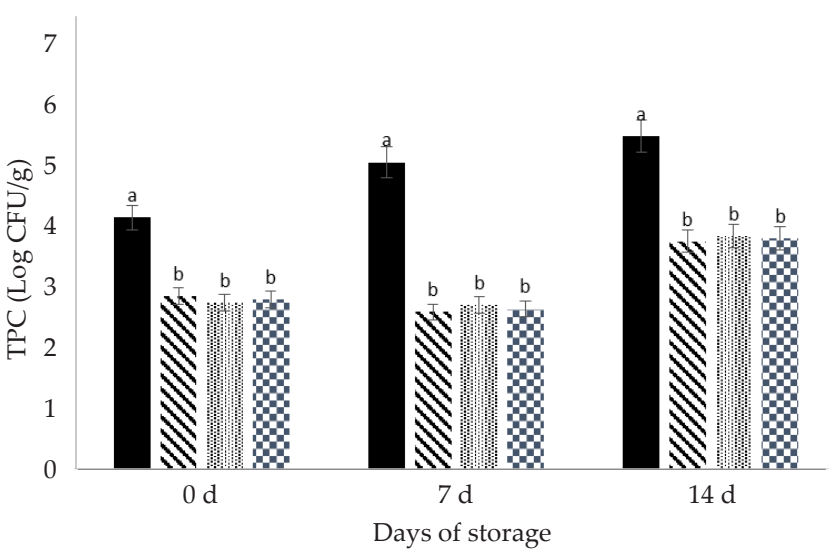

Figure 3. Total plate count (log CFU/gram) of lamb sausage as influenced by the levels of green tea leaves powder (GTP) during days of storage at a refrigerator temperature. GTP= Green tea powder; CON GTP 0\% ( ) = control, sausage with no GTP addition; GTP $1 \%$ ( . $=$ sausage $+1 \%$ GTP; GTP $1.5 \%$ ( $1.5 \%$ GTP; GTP $2 \%$ ( superscripts in the same group (days of storage) differ significantly $(\mathrm{p}<0.05)$. 


\section{Sensory Evaluation}

The sensory characteristics of lamb sausages with GTP incorporation are presented in Table 3. The average score for color, flavor, and odor was higher for sausages receiving GTP compared to control. The mean score of sausage color was 1.46 for sausage without GTP while for sausages treated with $1 \%, 1.5 \%$, and $2 \%$ GTP were $2.83,3.22$, and 3.53, respectively. Similar trends were also observed at flavor and odor score whereas the higher levels of GTP, the higher score of the sausage (Table 3). In contrast, there was a reduction trend on overall acceptability of sausage added by GTP. Sausage acceptability score was 3.72 for control group and reduced to 2.30 with $2.0 \%$ GTP addition.

\section{DISCUSSION}

\section{Chemical Composition and Physical Characteristics}

The result of the chemical composition of sausage added green tea leaves powder (GTP) was in line with the finding that bean inclusion as a source of protein alternatives into the meat product resulted in lower protein content. However, it was also in contrast with similar study using green tea extract and other plant extracts (Alirezalu et al., 2019). The lower protein content after adding GTP can be due to the lower protein concentration of GTP in comparison with lamb meat. Zhong et al. (2015) analyzed that green tea contains 15\% protein while lamb meat contained $25 \%$ protein. Dealing with sausage quality standards, the Indonesian National Standards (Indonesian National Standard; SNI 01-38202015) had determined that the minimum protein content of lamb sausage was $13 \%$. Thus, either without or with green tea addition, the lamb sausage in this research was still in accordance with the SNI quality.

In many studies, the $\mathrm{pH}$ values of meat products decrease when green tea extracts are included (ViudaMartos et al., 2010) that are mainly due to lactic acid bacterial growth. Since the $\mathrm{pH}$ value in this study did not change, the bacterial count as expressed in the number of TPC also did not change over the days of storage. The longer the storage time in the refrigerator, the higher the water holding capacity. The highest water holding capacity was achieved at 14-days of storage. Jayawardana et al. (2019) observed no changes with sausages treated by black tea and green tea extract in the levels of $0.05 \%$ and $0.30 \%$ that measured until $5 \mathrm{~d}$ of storage. Similarly,

Table 3. Sensory characteristics of lamb sausage as influenced by the levels of green tea leaves powder (GTP)

\begin{tabular}{lcccc}
\hline \multirow{2}{*}{ Variables } & \multicolumn{4}{c}{ Levels of GTP $(\%)$} \\
\cline { 2 - 5 } & 0.0 & 1.0 & 1.5 & 2.0 \\
\hline Color & 1.46 & 2.83 & 3.22 & 3.52 \\
Flavor & 1.61 & 2.58 & 3.04 & 3.32 \\
Odor & 1.47 & 2.55 & 3.00 & 3.23 \\
Texture & 3.10 & 3.22 & 3.37 & 3.45 \\
Overall & 3.72 & 3.14 & 2.68 & 2.30 \\
acceptability & & & & \\
\hline
\end{tabular}

Gai et al. (2014) also found that green tea powder did not influence the WHC of meat products. Jayawardana et al. (2019) suggested that the factors causing a high water-holding capacity are water content, protein, and salt use. In line with the increased protein content at 7 $\mathrm{d}$ and $14 \mathrm{~d}$ in comparison with $0 \mathrm{~d}$, it can be the reason for increasing WHC value. The protein content of meat products is known to have a good ability to bind water thus increase the WHC. This result agreed with Feng et al. (2013) who reported that adding meat products with protein sources increased WHC. Chattopadhyay et al. (2019) also provided evidence that adding sausages with chitosan improved the WHC due to stronger matrix formation associated with cross-linking of amino acids from chitosan and protein in the sausages. WHC is an important indicator indicating water entrapping capacity in which contributes to shelf life of meat products as a result of enhancing the emulsion integrity (Chattopadhyay et al., 2019).

\section{Oxidative Stability and Total Plate Count}

Sausages from lamb meat are highly susceptible to deteriorate since lipid oxidation is being a major problem thus affects their chemical, physical, and sensory qualities. The peroxide value measures the formation of peroxide or hydroperoxide groups that are the initial products of lipid oxidation (Wang et al., 2019). The incorporation of 1\% GTP to lamb sausage resulted in a decrease of lipid oxidation by $40 \%, 36 \%$, and $38 \%$, respectively during storages in comparison with the control. The results were in line with studies by Bozkurt (2006), Schilling et al. (2018), and Jayawardana et al. (2019) who reported that green tea extract significantly reduced TBARS values in beef and pork sausages. Qin et al. (2013) suggested that the primary mechanism of antioxidants from phenolic compounds in controlling lipid oxidation is mainly due to their capacities in chelating metal ions and trapping reactive oxygen species. Additionally, the antioxidant activity is depending upon the level of addition and plant extract or source type, primarily in accordance with their chemical structures, polarities, and interactions with the other components thereby providing sufficient protection against oxidative deterioration (Schilling et al., 2018).

During storages, there were no changes occurred in the number of TPC indicating that the sausages were well preserved. It was supported by the data of $\mathrm{pH}$ (Table 2) that did not change during the storage. The factor that can be linked to the unchanged data of TPC can be correlated to the strict hygienic practices followed during the production process. According to Badan Standardisasi Nasional (2015), Indonesian National Standard/ SNI 3820:2015 for meat sausages, TPC level in this study meets the regulation requirement in which not exceed at $1 \times 10^{5} \mathrm{CFU} / \mathrm{g}$ or $5 \mathrm{Log} \mathrm{CFU} / \mathrm{g}$ as the maximum concentration for TPC. It was very rational for using green tea extract or in the form of powder as a natural antibacterial to inhibit gram-negative bacteria involved in sausage deterioration due to its multipurpose power. Green tea extract had been largely reported to exhibit antimicrobial, antiviral, and anticarcinogenic 
activities (Alirezalu et al., 2019; Fernández et al., 2018; Aminzare et al., 2018). Epigallocatechin gallate (EGCG) and (-)-epicatechin gallate (ECG) are identified as the major bioactive antimicrobial compounds that are present in green tea powder (Schilling et al., 2018). The mode of action of these compounds can be either penetrate into the cell of microbes or cause changes in membrane permeability that results in cell leakage (Simpson \& Sofos, 2009).

In this study, higher usage ( $>1 \%$ ) of GTP did not affect the number of TPC that can be associated with a good stability of sausage preservation. For another reason, it could be related to the presence of positivegram bacteria in the packages, so the GTP suppression effect was maximum. In the early fermentation phase, rapid growth of bacteria is commonly occurred due to the high-water activity and appropriate $\mathrm{pH}$ (Sun et al., 2018). A similar trend of the number of TPC over storage time can also be associated with the stability of physical and chemical properties. From this study, it can be concluded that in powder form, green tea also could be used as a natural antimicrobial agent in lamb sausage.

\section{Sensory Quality}

The lower value of acceptability of the sausage added by GTP can be associated with bitter flavor of the GTP and its very fragrant smell. As stated by Schilling et al. (2018), the bitter tastes of green tea, mainly when added in high concentration in meat products becomes the reason to be rejected by consumer. Cai et al. (2015) suggested that despite the sensory quality, physical and microbiological quality of sausages also influenced acceptability. However, since the water holding capacity, tenderness, and $\mathrm{pH}$ showed similar trend among treatments, the lower score of acceptability in the lamb sausages with GTP was more likely caused by natural favor of GTP itself.

The current findings were in contrast with Alirezalu et al. (2019) who reported that adding 500 ppm green tea extract into beef sausages had no negative effect on color stability and sensory quality. It might be due to the different forms of green tea in which powder had a stronger effect on flavor and color than extract. Furthermore, high levels of GTP was also can be correlated, as many studies reported, with lower doses of usage of green tea extract. For instance, Jayawardana et al. (2019) reported no significant changes in color, odor, and overall acceptability of sausages added with $0.3 \%$ of green tea extract, possibly because the extract form is more concentrate and other substances from green tea that may cause adverse effect was removed. This study also confirmed that despite the lower acceptability, adding GTP by $2 \%$ improved odor quality that might be correlated with the reduced smell of the lamb meat. Although some authors reported that natural plant extracts improved sensory quality of sausages, the current findings postulated that it is depending upon the types of plant, meat products, form of natural ingredients.

\section{CONCLUSION}

The present study concluded that the incorporation of different levels of green tea leaves powder to lamb sausage had significant inhibition effects on the number of total plate count and effectively decreased lipid oxidation during storage. The green tea leaves powder also showed few changes in chemical and physical properties of lamb sausage. However, powder form of green tea was ineffective at improving sensory quality of the sausage, primarily on the reduction of overall acceptability due to their bitter taste.

\section{CONFLICT OF INTEREST}

The authors state that there is no conflict of interest with any financial, personal, or other relationships with other people or organization related to the material discussed in the manuscript.

\section{ACKNOWLEDGEMENT}

The authors thank the Faculty of Animal Science Universitas Gadjah Mada for providing research funding in the scheme of "Program Hibah Pascasarjana" to conduct this research as part of master thesis of the first author.

\section{REFERENCES}

AMSA. 1995. Research guidelines for cookery, sensory evaluation, and instrumental tenderness measurement of fresh meat. Am. Meat Sci. Assoc., Chicago.

AOAC. 2005. Official Methods of Analysis of AOAC International. 18th ed. Assoc. Off. Anal. Chem., Arlington.

Alirezalu, K., Hesari, J., Nemati, Z., Munekata, P.E.S., Barba, F.J., \& J.M. Lorenzo. 2019. Combined effect of natural antioxidants and antimicrobial compounds during refrigerated storage of nitrite-free frankfurter-type sausage. Food Res. Int. 120: 839-850. https://doi.org/10.1016/j. foodres.2018.11.048

Aminzare, M., Tajik, H., Aliakbarlu, J., Hashemi, M., \& M. Raeisi. 2018. Effect of cinnamon essential oil and grape seed extract as functional-natural additives in the production of cooked sausage-impact on microbiological, physicochemical, lipid oxidation and sensory aspects, and fate of inoculated Clostridium perfringens. J. Food Saf. 38: 1-10. https://doi.org/10.1111/jfs.12459

Badan Standardisasi Nasional. 2015. Sosis. Standar Nasional Indonesia (Indonesian National Standard) 3020. Jakarta, Indonesia.

Bansal, S., Choudhary, S., Sharma, M., Kumar, S.S., Lohan, S., Bhardwaj, V., Syan, N., \& S. Jyoti. 2013. Tea: A native source of antimicrobial agents. Food Res. Int. 53: 568-584. https://doi.org/10.1016/j.foodres.2013.01.032

Bozkurt, H. 2006. Utilization of natural antioxidants: Green tea extract and Thymbra spicata oil in Turkish dry-fermented sausage. Meat Sci. 73: 442-450. https://doi.org/10.1016/j. meatsci.2006.01.005

Cai, L., Cao, A., Li, Y., Song, Z., Leng, L., \& J. Li. 2015. The effects of essential oil treatment on the biogenic amines inhibition and quality preservation of red drum (Sciaenops ocellatus) fillets. Food Control. 56: 1-8. https://doi.org/10.1016/j. foodcont.2015.03.009 
Chattopadhyay, K., Xavier, K.A.M., Layana, P., Balange, A.K., \& B.B. Nayak. 2019. Chitosan hydrogel inclusion in fish mince based emulsion sausages: Effect of gel interaction on functional and physicochemical qualities. Int. J. Biol. Macromol. 134: 1063-1069. https://doi.org/10.1016/j. ijbiomac.2019.05.148

Feng, T., Ye, R., Zhuang, H., Rong, Z., Wang, Y. \& Z. Jin. 2013. Physicochemical propeties and sensory evaluation of Mesona Blumes gum / rice starch mixed gels as fat-substituts in Chinese Cantonese-style sausage. J. Food Resour. 50(1): 85-93.

Fernández, M.V., Agüero, M.V., \& R.J. Jagus. 2018. Green tea extract: A natural antimicrobial with great potential for controlling native microbiota, Listeria innocua and Escherichia coli in fresh-cut beet leaves. J. Food Saf. 38: 1-9. https://doi.org/10.1111/jfs.12374

Franco, D., Rodríguez-Amado, I., Agregán, R., Munekata, P.E.S., Vázquez, J.A., Barba, F.J., \& J.M. Lorenzo. 2018. Optimization of antioxidants extraction from peanut skin to prevent oxidative processes during soybean oil storage. LWT - Food Sci. Technol. 88: 1-8. https://doi.org/10.1016/j. lwt.2017.09.027

Gai, F., Gasco, L., Ortoffi, M., Gonzáles-Rodríguez, A., \& G. Parisi. 2014. Effects of green tea natural extract on quality parameters and lipid oxidation during storage of tench (Tinca tinca) fillets. J. Appl. Ichthyol. 30: 64-71. https://doi. org/10.1111/jai.12427

Jayawardana, B.C., Warnasooriya, V.B., Thotawattage, G.H., Dharmasena, V.A.K.I., \& R. Liyanage. 2019. Black and green tea (Camellia sinensis L.) extracts as natural antioxidants in uncured pork sausages. J. Food Process. Preserv. 43: 1-8. https://doi.org/10.1111/jfpp.13870

Jiang, J \& Y.L. Xiong. 2016. Natural antioxidants as food and feed additives to promote health benefits and quality of meat products: A review. Meat Sci. 120: 107-117. https:// doi.org/10.1016/j.meatsci.2016.04.005

Jongberg, S., Tørngren, M., \& L. Skibsted. 2018. Dosedependent effects of green tea or maté extracts on lipid and protein oxidation in brine-injected retail-packed pork chops. Medicines 5: 11. https://doi.org/10.3390/ medicines5010011

Kong, F \& R.P. Singh. 2011. Advances in instrumental methods to determine food quality deterioration. Food and Beverage Stabiligy and Shelf Life. Pp. 381-404.

Listyarini, K., Jakaria, Uddin, M.J., \& A. Gunawan. 2018. Association and expression of CYP2A6 and KIF12 genes related to lamb flavour and odour. Trop. Anim. Sci. J. 41(2): 100-107. https://doi.org/10.5498/tasj.2018.41.2.100

Lorenzo, J.M., Pateiro, M., Domínguez, R., Barba, F.J., Putnik, P., Kovačević, D.B., Shpigelman, A., Granato, D., \& D. Franco. 2018. Berries extracts as natural antioxidants in meat products: A review. Food Res. Int. 106: 1095-1104. https://doi.org/10.1016/j.foodres.2017.12.005

Nowak, A., Czyzowska, A., Efenberger, M., \& L. Krala. 2016. Polyphenolic extracts of cherry (Prunus cerasus L.) and blackcurrant (Ribes nigrum L.) leaves as natural preservatives in meat products. Food Microbiol. 59: 142-149. https://doi.org/10.1016/j.fm.2016.06.004

Perumalla, A.V.S. \& N.S. Hettiarachchy. 2011. Green tea and grape seed extracts - Potential applications in food safety and quality. Food Res. Int. 44: 827-839. https://doi. org/10.1016/j.foodres.2011.01.022

Qin, Y.Y., Yang, J.Y., Lu, H.B., Wang, S.S., Yang, J., Yang, X.C., Chai, M., Li, L., \& J.X. Cao. 2013. Effect of chitosan film incorporated with tea polyphenol on quality and shelf life of pork meat patties. Int. J. Biol. Macromol. 61: 312-316. https://doi.org/10.1016/j.ijbiomac.2013.07.018

SAS Institute, Inc. 2008. SAS User's Guide. Statistical Analysis Systems Institute, North Carolina.

Schilling, M.W., Pham, A.J., Williams, J.B., Xiong, Y.L., Dhowlaghar, N., Tolentino, A.C., \& J.L. Silva. 2018. Changes in the physicochemical, microbial and sensory characteristics of fresh pork sausage containing varying combinations of rosemary (Rosmarinus officinalis L.) and green tea (Camella sinensis L.) extracts during retail display. Meat Sci. 96: 453. https://doi.org/10.1016/j. meatsci.2013.07.065

Shekar, T.C. \& G. Anju. 2014. Antioxidant activity by DPPH radical scevenging method of Ageratum conyzoides Linn. Leaves. Am. J. Ethnomed. 1(4): 244-249.

Silva, S.L.D., Amaral, J.T., Ribeiro, M., Sebastião, E.E., Vargas, C., Franzen, F.L., Schneider, G., Lorenzo, J.M., Fries, L.L.M., Cichoski, A.J., \& P.C.B. Campagnol. 2018. Fat replacement by oleogel rich in oleic acid and its impact on the technological, nutritional, oxidative, and sensory properties of Bologna-type sausages. Meat sci. 149: 141-148. https://doi.org/10.1016/j.meatsci.2018.11.020

Simpson, C.A., \& J.N. Sofos. 2009. Antimicrobial ingredients. In R. Tarté (Ed.). Ingredients in meat products: properties, functionality and applications. New York, NY: Springer. pp. 301-377.

Sulmiyati, Said, N.S., Fahrodi, D.U., Malaka, R. \& F. Maruddin. 2019. The physicochemical, microbiology, and sensory characteristics of kefir goat milk with different levels of kefir grain. Trop. Anim. Sci. J. 42(2): 152-158. https:// doi.org/10/5398/tasj/2019.42.2.152

Sun, Q., Zhao, X., Chen, H., Zhang, C., \& B. Kong. 2018. Impact of spice extracts on the formation of biogenic amines and the physicochemical, microbiological and sensory quality of dry sausage. Food Control. 92: 190-200. https://doi. org/10.1016/j.foodcont.2018.05.002

Viuda-Martos, M., Ruiz-Navajas, Y., Fernández-López, J. \& J.A. Pérez-Álvarez. 2010. Effect of added citrus fibre and spice essential oils on quality characteristics and shelf-life of mortadella. Meat Sci. 85: 568-576. https://doi. org/10.1016/j.meatsci.2010.03.007

Wang, X., Xu, M., Cheng, J., Zhang, W., Liu, X., \& P. Zhou. 2019. Effect of Flammulina velutipes on the physicochemical and sensory characteristics of Cantonese sausages. Meat Sci. 154: 22-28. https://doi.org/10.1016/j.meatsci.2019.04.003

Warner, R. 2014. Measurement of water-holding capacity and color: objective and subjective. Encycl. Meat Sci. 2: 164-171. https://doi.org/10.1016/B978-0-12-384731-7.00210-5

Yang, C.S., \& J.M. Landau. 2000. Effects of tea consumption on nutrition and health. J. Nutr. 130: 2409-2412.

Zhong, R.Z., Li, H.Y., Fang, Y., Sun, H.X., \& D.W. Zhou. 2015. Effects of dietary supplementation with green tea polyphenols on digestion and meat quality in lambs infected with Haemonchus contortus. Meat Sci. 105: 1-7. https://doi. org/10.1016/j.meatsci.2015.02.003 